\title{
Societal Script und Verfassungsrecht als konkurrierende Grundlagen der Herrschaftsordnung Äthiopiens ${ }^{1}$
}

\author{
Von Heinrich Scholler
}

\section{Societal Script und Verfassungsrecht}

Nach dem Zusammenbruch des Mengistu-Regimes sucht Äthiopien nach einer neuen Herrschafts- und Legitimationsordnung. Dabei kommt der traditionellen Gesellschafts- und Legitimationsform wiederum erhöhte Bedeutung zu. Gleichzeitig wird aber die Frage aufgeworfen, welche instrumentale Funktion das moderne Recht, insbesondere das Verfassungsrecht, für die Umstrukturierung des äthiopischen Staates haben kann. Von äthiopischer Seite wurde gelegentlich behauptet, daB immer dann, wenn eine ausländische Macht in Berühning mit Äthiopien getreten sei, die Äthiopier eine Verfassung erhalten hätten. Diese Auffassung ist historisch nicht gerechtfertigt, denn schon im 16. Jahrhundert kannte der äthiopische Staatsverband eine Verfassungsurkunde, die Ser'ata Mangest, die eine sehr konkrete Beschreibung der äthiopischen Herrschaftswirklichkeit und des Herrschaftsanspruchs enthielt. 2 Die neue Aufgabe, die sich die Übergangsregienung Äthiopiens gestellt hat, muß vor allem die Frage beantworten, wieweit man bei der Neuorganisation dem Societal Script oder modemen verfassungsrechtlichen Konzeptionen folgt und inwieweit diese Neuorganisation eine Entsprechung zu der traditionellen Herrschaftslegitimation und Struktur haben soll.

Art. 2 der Ubergangsverfassung bringt zum Ausdruck, daß Äthiopien erst die verschiedenen National Societies und Verfassungen durch einen Vertrag zustandebringen sollte, $\mathrm{da} B$ diesen National Societies Selbstbestimmung auf kulturellem und religiösem Gebiet einzuräumen sei und daß diesen nationalen Gebilden das Recht der Selbstbestimmung bis hin zur Sezession eingeräumt werden müßte, wenn ihren Forderungen nach kultureller Autonomie nicht entsprochen werden könne.3 Entspricht dieses verfassungsrechtliche

1 Nachfolgende Ausführungen sollen dem Gedenken an meinen Freund Eike Haberland gewidmet sein.

2 Die Ser'ata Mangest geht auf Kaiser Amdé Seyon (1314-1344) und Gelawdewos (1540-1559) zurück. Sie wurde auch unter Kaiser Iyasu (1682-1706) überarbeitet und neu formulier. Zuerst wurde sie von $J$. Varenbergh, Studien zur abessinischen Reichsordnung, in: Zeitschrift für Assyrologie und verwandte Gebiete, Vol. 30 (1915), S. 41-45, übersetz. Siehe auch H. Scholler / Bairu Tafla, Ser'ata Mangest. An early Constitution, in: VRÜ (1976), S. $487 \mathrm{ff}$.

3 Transitional Period Charter of Ethiopia vom 22. Juli 1991; Art. 2 dieser Übergangsverfassung lautet: 
Postulat der äthiopischen Rechtskultur und der äthiopischen Geschichtsentwicklung? Oder müßte aus dem Geschichtsverständnis der Ruf nach einer Wiederholung der Zentralisierung unter Haile Selassie oder Mengistu folgen? Was erfordert die äthiopische Geschichte, oder besser, das Societal Script als hinreichende Legitimation von Herrschaft: Autonomie der Peripherie oder Stärkung und Oberhöhung der Zentralautorität?4

Erst in den 40er Jahren dieses Jahrhunderts war es Kaiser Haile Selassie gelungen, im Kampf gegen die italienische Okkupation die Autonomie der Peripherie, also den spätföderativen Feudalismus zu überwinden und dafür eine Zentralautorität unter kaiserlicher Kontrolle zu errichten. Schon der späte Zeitpunkt der Durchsetzung der Zentralautorität des äthiopischen Staates gegenüber der Peripherie zeigt, daß es sich hierbei nicht um ein traditionelles Element äthiopischer Herrschaft handelt: So hoch auch der König der Könige in seiner Auctoritas war, seine Potestas entsprach nicht dem des europäischen absoluten Herrschersystems, so daß Auctoritas und Potestas weit auseinandertraten.

Mit dieser ersten Frage verbindet sich eine zweite, die der Interaktion zwischen Äthiopien und den anderen nordostafrikanischen Staaten nachgeht. Es ist erforderlich, daß Äthiopien sich für das Agieren innerhalb Afrikas bzw. der intemationalen Staatenwelt ein Herrschafsmodell zulegt, das den westlichen Modellen kongruent ist. Die Sezession Eritreas und die Betonung der historischen Autonomie der Peripherie Äthiopiens könnte so verstanden werden, daß eine historische Wiederherstellung relativ selbständig agierender Staatsgesellschaften gegenüber dem nationalen Einheitsstaat vorzuziehen ist, weil sie der äthiopischen Geschichte mehr entspreche.

So einfach läßt sich aber in der modemen Staatenwelt die Frage nicht stellen, denn Äthiopien oder die Nachfolgestaaten müssen weiterhin in der Lage sein, im intemationalen Rahmen zu agieren. Eine Reduktion auf 14 Staaten entsprechend der Neugliederung Äthiopiens würde nicht nur zu einer dauemden Beunruhigung der Region führen, sondem

"The right of nations, nationalities and peoples to self-determination is affinned. To this end, each nation, nationality and people is guaranteed the right to:

a) Preserve its identity and have it respected, promote its culture and history and use and develop its language;

b) Administer its own affairs within its own defined territory and effectively participate in the central govemment on the basis of freedom, and fair and proper representation;

c) Exercise its right to self-determination of independence, when the concemed, nation/nationalities and people is convinced that the above rights are denied, abridged or abrogated."

4 In der Darstellung der Geschichte Äthiopiens wird regelmäßig die Zentralisierung unter Haile Selassie als Fortsetzung des zentralen und nationalstaatlichen Reformkaisertums angesehen; so z.B. A. Barlnicki / J. Mantel / Niecko, Geschichte Äthiopiens, Berlin 1971, Bd. 2, S. 222 und 549. Ebenso C. Clapham, Haile Selassie's Govemment, 1970, S. 75. Immerhin betont Clapham die Unterrepräsentation der anderen Stämme (siehe dazu den Anhang mit der Tabelle aus dem Buch Claphams, aus welcher die Überrepräsentation der Amharas deutlich hervorgeht). 
auch das Handeln nach außen fitr die einzelnen Einheiten unmöglich machen. Dennoch ist es wichtig, nach dem Societal Script zu fragen und einen Kompromiß zwischen den modernen Anforderungen an eine funktionelle Verfassung und der Akzeptanz traditioneller Rechtskultur herzustellen.

Eine interessante, wenn auch bei weitem nicht unbestrittene Analyse des Societal Scripts hat Donald Levine vorgelegt.5 Er untersuchte das Societal Script auf drei Ebenen: das Ganze als Einheit, das Ganze im Verhältnis zu seinen Teilen und die einzelnen Teile in ihrem Verhältnis zueinander. Auf diesen drei Ebenen kommt Levine dann zu seiner bekannten Gegenüberstellung von Thesis und Antithesis, wobei die hierarchische Gesellschaftsstruktur der Amhara und amhara-verwandten Ethnien der egalitären Akiphalen der Oromo gegenübergestellt wird. War Äthiopien in Geschichte und Gegenwart eine wirkliche Synthese dieser Thesis und Antithesis, wie es Levine darstellt? Wie ist das Experiment der äthiopisch-eritreischen Föderation, die 1952 endete, unter diesem Aspekt zu beurteilen?6

Nachfolgend sollen in Anbetracht der Tatsache, daß eine neue gesamtäthiopische Föderation bevorsteht oder geplant ist, die Fragen untersucht werden, ob Thesis oder Antithesis der beiden Gruppen von amharisch-tigreischen Ethnien oder der oromoischen Ethnien Grundlage einer föderativen Struktur von "Nationen", "Nationalitäten" oder "Völkem" sein kann, wie dies in Art. 2 der Übergangsverfassung Äthiopiens ausgedrückt wird. Daß Eritrea bereits den Diskussionsboden für eine Föderation verlassen hat und durch ein Referendum Anfang 1993 sich von Äthiopien ganz loslösen wird, scheint eine Tatsache zu sein. Doch auch diese Tatsache muß nicht bedeuten, daB nicht in Zukunft eine neue Föderation möglich ist, die dann zwischen einem neu strukturierten föderalen Äthiopien und Eritrea zu schließen wäre.

Somit ist die Frage zu beantworten, ob föderative Staatsstrukturen der äthiopischen Staatstradition völlig fremd sind oder ob es doch Ansatzpunkte dazu gibt. Die Theorie von der Amhara-Thesis und der Omoro-Antithesis scheint eine modeme Föderation im Gegensatz zur Feudalföderation eher zu erschweren, doch scheint Äthiopien in seiner Geschichte immer eine praktische Konkordanz dieser beiden gegensätzlichen Scruknuprinzipien gefunden zu haben.

5 DN. Levine, Greater Ethiopia, Chicago 1974; ders., Meles Zenawi and the Politics of Ethnicity, in: Ethiopia Review, Sept. 1992, S. 14; s.a. J.W. Harbeson, The Ethiopian Crisis: Altemative Scenarios for Change, in: Hom of Africa, Vol. XIII 3 \& 4, Vol. XIV 1 \& 2, S. 121.

6 Hinzuweisen ist hier auf die Vorräge, die 1990 an der Universität Leicester von bekannten Äthiopisten, darunter Bairu Tafla, Peter Woodward, Richard Greenfield, Asfa Wossen und C. Clapham gehalten wurden unddie demnächst in Druck gehen sollen. S.a. H. Scholler, Herrschaft und Reich in Äthiopien - Politische Anthropologie und Verf assungsrecht, in: Jungraithmayr / Kronenberg / Strieter (Hrsg.), Paideuma, Mitteilungen zur Kulturkunde, Afrika-Studien I, Eike Haberland zum 65. Geburtstag, Bd. 35, Wiesbaden 1989, S. $247 \mathrm{ff}$. 


\section{Vertikale und Horizontale}

1. Die soziale Struktur und die geistig-mystische Hierarchisierung waren in Äthiopien immer zwei Faktoren, die Staat und Gesellschaft durchdrungen und markant bestimmt haben. Die pluralistischen Ethnien können gleichsam als die Horizontale, die Dominanz der Amhara und Tigre in dieser Völkergemeinschaft mit ihrem geistig-mystischen Ủberbau als die Vertikale in der Geschichte dieser Kultur und dieses Landes verstanden werden. Zur Vertikalen gehören gerade auch die beiden beherrschenden Staatssozietäten, die Amhara und die Tigre, die es verstanden haben, den Geschichtsmythos in ihren Dienst zu nehmen.

Von großer Bedeutung für Äthiopien ist immer ein gewisser Geschichtsmythos gewesen. Er beginnt mit dem König Salomon und der Königin von Saba, setzt sich in der Legende vom Priesterkönig Yohannes fort und endet in gewissem Sinne im Mythos des wiedererstandenen Kaisers, der wiederkommt, um den Glauben zu reinigen, das Reich wiederherzustellen und die Weltherrschaft von Jerusalem aus anzutreten.7 Das revolutionäre Äthiopien hat diesen klassischen Mythen einen neuen hinzugefügt: den Mythos vom 3000-jährigen Klassenkampf der entrechteten äthiopischen Landarbeiter gegen die Feudalherrschaft. 8

2. Im Ablauf der 3000-jährigen Geschichte haben sich Horizontale und Vertikale verändert. Diese Veränderung bezog sich auf die Struktur und auch auf die Funktion der Komponenten. Herrschaft und Reich wurden von der Horizontalen und Vertikalen entscheidend beeinflußt.

3. Die Vertikale mündet in der Idee des "Königs der Könige" (negusa negest), die sich mit der Vorstellung des siegreichen Löwen von Juda verbindet. 9 Einen wichtigen Hinweis zum Verständnis von Reich und Herrschaft liefert die Übersetzung des Kosmas Indikopleustes im 6. Jahrhundert. 10 Die von Kosmas versehentlich mitübersetzte Inschrift des Monumentum Adulitanum, eines noch unbekannten äthiopischen Königs aus dem ersten nachchristlichen Jahrhundert, lautet:

7 Zu den Äthiopiem in Jerusalem s. K. Petersen, The History of the Ethiopian Community in the Holy Land from the Time of Emperor Tewodros П, Hill 1974; ders., Studia Oecumenica Hierosolymitana, Bd. 2, Jerusalem 1983, insb. S. 30 ff. Petersen hat jedoch die Zeit von Kaiser Yohannes IV nicht berücksichtigt, insb. nicht die von Bairu Tafla zitierten Briefe des Kaisers an die äthiopischen Mönche im Kloster in Der Seltan; Bairu Tafla, Chronicle of Emperor Yohannes IV (18721889), in: Äthiopistische Forschungen, Bd. 1, Wiesbaden 1977, insb. S. $171 \mathrm{ff}$.

8 So z.B. Tadesse Tamrat, Feudalism in Heaven and on Earth: Ideology and Political Structure in Medieval Ethiopia, in: Proceedings of the Seventh International Conference of Ethiopian Studies, hrsg.v. Sven Rubenson, Berlings-Arlöv/Schweden 1984, S. 195.

9 E. Ullendorff, Ethiopia and the Bible, London 1968, S. 11 unter Hinweis auf Rubensons Arbeiten.

10 Zitiert nach Segew Hable Selassie, Ancient and Medieval Ethiopian History to 1270, Addis Ababa 1972, S. 15. 
"Alle diese Völker habe ich als erster und einziger von den Königen vor mir unterworfen durch die Gnade, die ich bei meinem erhabenen Gott Ares habe, der mich auch erzeugt hat, durch den ich alle Länder, die an mein Land angrenzen im Osten bis zum Weihrauchlande, im Westen bis zu den Ländern von Äthiopien und der Sasu, meiner Herrschaft unterwarf, die einen, indem ich selbst auszog und sie erfocht, die anderen, indem ich zu ihnen schickte. Und als ich in der ganzen mir unterworfenen Welt Frieden hergestellt hatte, kam ich nach Adulis, um dem Zeus und dem Ares und dem Poseidon für die Seefahrenden zu opfern...".11

Das Interessanteste an dieser Reichsidee ist, daß der König eine mittelbare Herrschaft über die Völker, die er unterworfen hatte, ausübte. Er ist König und nicht König von Königen. Bemerkenswert ist auch die Idee des Weltfriedens, die auf eine Imperiumsidee hinweist. Eine zweite Inschrift berichtet und dies ebenfalls nur indirekt, und zwar über die Christianisierung durch König Ezana im 4. nachchristlichen Jahrhundert. 12 Hier wird die Herrschaft auf ein Gottwesen, das als Herr des Himmels oder Herr des Landes (äthiopischer Begriff für Gott = egzi' abeher) bezeichnet wird, gegrindet. Diese Herrschaft wird unmittelbar über die Völker ausgeübt und ist unmittelbar von Gott, nicht mittels anderer Mächte verliehen. Der Monotheismus verstärkt somit die Zentralherrschaft. Das scheint ein Kennzeichen äthiopischer Herrschaft zu Beginn der aksumitischen Periode zu sein, das über eineinhalb Jahrtausende verfolgt werden kann. 13

Die Vertikale wird außerdem von der äthiopischen Kirche gebildet, die seit dem äthiopischen Mittelalter auf das engste mit dem Kaiser verbunden war. So war der Umstand ohne große Bedeutung, daß bis nach dem zweiten Weltkrieg der oberste äthiopische Bischof ein Ägypter war. Zum Vertikalen gehören sowohl der Einfluß des Ge'ez und des Amharischen als Staatssprache als auch der Führungsanspruch, den Äthiopien immer und auch nach der Befreiung Afrikas geltend gemacht hat.

In der Darstellung der Gerichtsbarkeit in der äthiopischen Volksmalerei wird die Stärkung der verschiedenen hierarchisch-geistigen Mächte Kaiser und Kirche in der Organisation des Kaisergerichts deutlich ausgedrückt. Denn nur Vertreter des Klerus haben offenbar das Recht, dem kaiserlichen Gerichtskörper aus dem Gesetzbuch des Feta Nagast die einschlägigen in Frage kommenden Rechtsregeln vorzutragen. Hier galt noch nicht der römischrechtliche Grundsatz: jura novit curia. Das Recht, das wesentlich kanonisch und römisch-

11 Sergew Hable Selassie, a.a.O., S. 63.

12 Die Aksum-Inschrift Nr. 11 beruft sich auf den Herm des Himmels, der den Herrscher geschaffen habe, den Herm des Alls, von dem er geliebt werde. S. auch in ähnlichen Dokumenten bei Sergew Hable Selassie, a.a.O., S. 103, 105.

13 Das Amhara-Zentralland, die Amhara-Tigre-Zentralgebiete und die amharischen Einflußsphären, umgeben von muslimischen und heidnischen Gebilden um 1520, zeigt eine Abbildung bei $D N$. Levine, Greater Ethiopia, The Evolution of a Multiethnic Society, Chicago 1974, S. 76. 
syrisch war, mußte dem Gericht vermittelt werden. Ich habe dies in einer Untersuchung über die Open Air Courts in der äthiopischen Volksmalerei vor einiger Zeit dargestellt.14

4. Die Horizontale wird von den Völkergemeinschaften gebildet, die die äthiopische Region besiedeln. Sie setzt sich in der Sprachenvielfalt und im Aneinanderrücken der Großreligionen und ihrer verschiedenen regionssoziologischen Strukturen fort. Von besonderer Bedeutung sind die drei ethnischen Schichtungen und die sozialen und politischen Ordnungsvorstellungen, die ihnen entsprechen. Diese rassisch-ethnischen Gruppen lassen sich grob in semitische, kuschitische und nilotische Völker aufgliedem. Neben dem Amharischen, dem Tigre und anderen verwandten semitischen Sprachen stehen die kuschitischen Sprachen. Hierzu gehören die Bega in Eritrea, die Agaw mit ihren verschiedenen Dialekten, die Afar in der Danakil-Wüste, die Oromo-Gruppen und die Sidamo-Völker im Westen. Als dritte Schicht kann man die nilotischen oder negroiden Stämme bezeichnen. Sie siedeln vor allem an der Westgrenze Äthiopiens.

Diese Vielfalt der Völker und die sprachliche Pluralität verbinden sich mit einer völlig anderen Form von Herrschafts- und Reichsdenken. Wir finden bei den Oromo15, aber auch bei den Nuer16 oder den Anuak eine Form der segmentären Gesellschaft.17 In gewisser Hinsicht bildet das Gadda-System ein Zwischenglied zwischen kephaler und segmentärer Gesellschaftsordnung, da ihr Klan-System ebenfalls segmentär ist, aber doch ein besonderes System der Herrschaft, das sogenannte Gadda-System aufbaut. In Abständen von acht Jahren treten die so zusammengefaßten Geburtsjahrgänge in verschiedene politische und militärische Funktionen ein. In der fünften Gadda-Stufe erreicht der Mann politisch und familiär seine höchste Stellung, während sich die Väter aus dem politischen Leben zurückziehen.

In der äthiopischen Geschichte haben die jetzt stark amharisierten Oromo jahrhundertelang den Bestand des amharischen Reiches und der amharischen Herrschaft bedroht. Die "heidnischen Galla" wurden mit Gewalt unterworfen, christianisiert und dem Reichsverband eingegliedert. Oromo-Adelige verbanden sich mit dem amharischen Königshaus, während

14 H. Scholler / Girme Fisseha, Ethiopian Open Air Courts in Popular Paintings, in: Afrika und Übersee, Bd. 68, Heft 2, Berlin 1985, S. 11 ff.

$15 S$. Haberland, Galla Süd-Äthiopiens, mit einem Beitrag von K. Reinhardt, Zeichnungen und Karten von Ute Silz-Riebandt. Mit einer englischen Zusammenfassung, Stultgart 1963, bzgl. der Borana S. 115 ff., der Gugi (Alabdu) S. 291, der Uraga, Mati und Hoku S. 376 ff. und der Arussi S. $438 \mathrm{ff}$.

16 E. Pritchard, Nuer. A Description of the Modes of Livelihood and Political Institution of a Nilotic People, Oxford 1940, insb. S. 139. Eine Zusammenfassung der Nuer-Forschung findet sich bei $U$. Wesel, Frühf ormen des Rechts in vorstaatlichen Gesellschaften, Frankfurt 1985, S. 239.

17 Statt vieler E.R. Service, Origins of the State and the Civilisation - The Process of Cutural Revolution, deutsch: Ursprünge des Staates und der Zivilisation - Der Prozeß der kulturellen Revolution, Frankfurt 1977. 
die Zerstörung der Oromo-Kultur durch eine Feudalverwaltung im Süden rasch voranschritt. 18 Die führenden Offiziere der äthiopischen Armee setzten sich überdurchschnittlich aus Oromo-Abkömmlingen zusammen. So brach die "domestizierte Horizontale" in die "amharisch vertikale" Herrschaftsstruktur ein. Man hat die äthiopische Revolution, die den Derg, den Militärrat, zur Macht brachte, auch die Rache der Oromo genannt, weil eine Mehrheit von Oromo-Delegierten zeitweise den Derg majorisieren konnte. Ob sich diese Auffassung allerdings halten läßt, scheint zweifelhaft.

Von größerer Bedeutung für unser Thema ist aber die Zusammenstellung der Systemstrukturen und der Gruppenaktivitäten der Amhara und Oromo, die Levine als Thesis und Antithesis der äthiopischen Kultur bezeichnet. 19 Sicher bedarf die Horizontale einer strukturellen Durchleuchtung.

\section{Thesis und Antithesis}

1. Die amharische Thesis wird als hierarchisch-individuell, die Antithesis als egalitärkollektiv bezeichnet. Allerdings kann ich, wie schon gesagt, mit der Einordnung des Oromo-Systems und seiner strukturellen Eigenheiten mit Levine nicht übereinstimmen. Unser Problem zeigt sich vor allem bei der Beurteilung der autonomen politischen Sphäre (Autonomous Political Sphere) des Societal Script und der Systemstabilität. Hier sind die Angaben Levines für das Amhara-System: hoch (high), für das Oromo-System: niedrig (low). Besonders stark unterscheidet sich das Societal Script, das für das amharische System im Hinblick auf die historische Projektion als imperialistisch-expansiv gekennzeichnet wird, während es bei den Oromo als zyklisch-klassenstrukturell erscheint. Es ist jedoch hier nicht möglich, die Gründe, warum ich Levines antithetische Gegenüberstellung, vor allem aber die Abwertung des Oromo-Systems, für unrichtig halte, darzutun. 20

Eine wichtige Bedeutung für die Horizontale und die Vertikale kommt dem Umstand zu, $\mathrm{da} ß$ selbst die Amhara und nicht nur die Oromo keine Städte im modemen Sinne gegründet haben. Die "Katema"-Städte sind eher Wehrpfalzen. Zwischen ihnen bewegten sich der König und seine Truppen hin und her. Dieser Mangel an zentralisierter Stadtkultur und Stadtverwaltung, der wohl in der gondar-Periode, wenn auch nur zeitweise, überwunden wurde, hat weiter dazu beigetragen, die Horizontale in der äthiopischen Sozialordnung zu betonen.

18 Für die Hadiya wurde dies von U. Braukämper, Geschichte der Hadiya Süd-Äthiopiens, in: Studien zur Kulturkunde, Nr. 50, insb. S. 294 f. dargestellt.

19 DN. Levine, Greater Ethiopia, The Evolution of a Multiethnic Society (FN 13).

20 Das Gadda-System erinner etwas an den Elitenzirkulationsprozeß, wie er in der politischen Soziologie diskutien wird. 
2. Ein interessanter Beweis für die horizontale Struktur im Societal Script der äthiopischen Gesellschaft ist in der Ser'ata Mangest, jener mittelalterlichen Verfassungsurkunde zu finden, die von Varenbergh übersetzt wurde.21 Neben der Dualität von Kirche und Staat fällt die zahlreiche und auf verschiedenen Ebenen stattfindende Aufteilung in rechts und links auf, die die Vertikale, unterhalb der Königsebene, auf den verschiedenen Stufen der Hierarchie durchzieht und bef estigt. Bei verschiedenen Anlässen, wie z.B. dem Einzug des Königs in Aksum, bei der Ordnung des zeremoniellen Königszuges, ist die Vertikale stark betont (Ser'ata Mangest, III 2). Zahlreich sind die Angaben und Hinweise, welche die Horizontale in der Rechts-Links-Anordnung hervorheben, so z.B. die 22 Gesetzgeber (Getoch) zur Rechten und zur Linken (Ser'ata Mangest, I). Daß diese horizontale Zweiteilung später einem Erosionsprozeß zugunsten der hierarchischen OTdnung unterlag, zeigt die Erwähnung des Beht Wadad, von dem die Ser'ata Mangest (III 17) sagt, daß es ursprünglich zwei Beht Wadad gab, nämlich einen zur Rechten und einen zur Linken.

\section{Schluß}

Diese historische und soziale Verfaßtheit der äthiopischen Gesellschaft in vertikaler und horizontaler Richtung gilt es, in einer modemen adäquaten Verfassungsstruktur zu restrukturieren. Verf assung ist insofern nicht Neugründung (institutio), sondern Zusammenfügung von Bestehendem (constitutio).

Eine Überbetonung der Vertikalen und Horizontalen im Societal Script wie eine Überforderung von Thesis und Antithesis könnte als Postulat eines überzogenen Selbstbestimmungsrechtes verstanden werden, das beliebige Sezessionen rechtfertigen würde. Es muß vielmehr eine Versöhnung oder Harmonisierung der vertikalen und horizontalen Elemente der äthiopischen Tradition versucht werden. Dazu kann die politische Anthropologie genauso beitragen wie das modeme Verfassungsrecht. Die Staatenpraxis hat genügend Modelle föderativer Kooperation aufgezeigt. Diese müssen unter den Bedingungen anthropologischer Eignung auf ihre Anwendbarkeit und Zweckmäßigkeit für die Neuordnung Äthiopiens untersucht werden.

21 Joseph Varenbergh, Studien zur äthiopischen Reichsordnung, in: Zeitschrift für Assyriologie und verwandte Gebiete, hrsg. von C. Betzold, Bd. 30, Teildruck, Straßburg 1915. 


\section{Anhang \\ Transitional Period Charter of Ethiopia}

Whereas the overthrow of the military dictatorship that has ruled Ethiopia for seventeen years presents a historical moment, providing the Peoples of Ethiopia with the opportunity to rebuild the country and restructure the state democratically;

Whereas the military dictatorship was, in essence, a continuation of the previous regimes and its demise marks the end of an era of subjugation and oppression thus starting a new chapter in Ethiopian history in which freedom, equal rights and self-determination of all the peoples shall be the governing principles of political, economic and social life and thereby contributing to the welfare of the Ethiopian Peoples and rescuing them from centuries of subjugation and backwardness;

Whereas peace and stability, as essential conditions of development, require the end of all hostilities, the healing of wounds caused by conflicts and the establishment and maintainance of good neighbourliness and co-operation;

Whereas for the fulfilment of the aforementioned conditions and for the reign of a just peace, the proclamation of a democratic order is a categorical imperative, and;

Whereas to this end, all institutions of repression installed by the previous regimes shall be dismantled, regional prejudicies redressed and the rights and interests of the deprived citizens saf eguarded by a democratic govemment elected by and accountable to the People;

Whereas from The Peace Loving and Democratic forces present in the Ethiopian society and having Varied Views, having met in a Conference convened from July 1-5 in Addis Ababa, have discussed and approved the charter laying down the rules governing The Transitional Government as well as setting down the principles for the transitional period,

Now, therefore, it is hereby proclaimed as follows;

\section{Part One \\ Democratic Rights}

\section{Article One}

Based on the Universal Declaration of Human Rights of the United Nations, adopted and proclaimed by the General Assembly by resolution 217 A (III) of 10 Dec. 1948, individual 
human rights shall be respected fully, and without any limitation whatsoever. Particularly every individual shall have:

a) The freedom of conscience, expression, association and peaceable assembly;

b) The right to engage in unrestricted political activity and to organize political parties, provided the exercise of such right does not infringe upon the rights of others.

\section{Article Two}

The right of nations, nationalities and peoples to self-determination is affirmed. To this end, each nation, nationality and people is guarranteed the right to:

a) Preserve its identity and have it respected, promote its culture and history and use and develop its language;

b) Administer its own affairs within its own defined territory and effectively participate in the central govemment on the basis of freedom, and fair and proper representation;

c) Exercise its right to self-determination of independence, when the concerned, nation/ nationality and people is convinced that the above rights are denied, abridged or abrogated.

\section{Part Two \\ Principles Guiding Foreign Policy}

The Transitional Govemment will conduct its foreign relations on the basis of the principles of respect for the sovereignity and equality of states and non-intervention and noninterference in internal affairs, as well as the promotion of mutual interests. Accordingly:

\section{Article Three}

The policy of distabilization and conflict-promotion hitherto actively pursued by the previous regime with respect to the country's neighbours shall cease forthwith with the issuance of this Charter.

\section{Article Four}

It shall abide by all mutual agreements that respect the sovereignity of Ethiopia and are not contrary to the interests of the People.

\section{Article Five}

Local govemments shall have the right to establish direct contact with relief organizations with respect to relief work. 


\section{Part Three \\ Structure and Composition of the Transitional Government}

\section{Article Six}

There shall be established a Transitional Government consisting of a Council of Representatives and a Council of Ministers.

\section{Article Seven}

The Council of Representatives shall be composed of representatives of national liberation movements, other political organizations and prominent individuals to make-up a total of no more than 87 members.

\section{Article Eight}

The Transitional Govemment shall exercise all legal and political responsibility for the governance of Ethiopia until it hands over power to a government popularly elected on the basis of a new Constitution.

\section{Article Nine}

The Council of Representatives shall exercise legislative functions as follows and oversee the work of the Council of Ministers:

a) draw-up its rules of procedure;

b) election of its Chairperson, who shall also be the Head of State, and a Vice-Chairperson and Secretary, the Head of State shall appoint the Prime Minister, whose appointment shall be approved by the Council of Representatives. The Head of State, the Prime Minister, the Vice-Chairperson and Secretary of the Council of Representatives shall be from different nations/nationalities;

c) approve the Prime Minister's nomination of the members of Council of Ministers drawn-up on considerations of ascertaining a broad national representation, technical competence and unswerving adherence to the Charter;

d) initiation and promulgation of proclamations and decrees pursuant to the Charter;

e) adoption of national budget;

f) provide for the administration of justice on the basis of the Charter, the Courts shall, in their work, be free from any governmental interference with respect to items provided for in Part One, ArticleOne of the Charter;

g) establish the Constitutional Commission;

h) ratify intemational agreements;

i) create committees for defence and security policy during the transitional period;

j) provide the mechanism to ascertain the fair and impartial application of the mass media;

k) issue just labour law that protects the rights and interests of the workers. 


\section{Part Four \\ Transitional Programme}

The following provisions for a transitional period have been adopted in order to lead the country towards full democracy.

\section{A. Political}

\section{Article Ten}

The Council of Representatives shall constitute the Constitutional Commission to draw up a draft constitution.

The Constitutional Commission shall submit to the Council of Representatives the draft constitution.

\section{Article Eleven}

Upon adoption of the draft constitution by the Council of Representatives, the Constitution shall be presented to the people for discussion.

The final draft shall be presented for adoption to the Constituent Assembly to be elected pursuant to the final draft of the Constitution.

\section{Article Twelve}

Elections to a National Assembly shall be held on the basis of the provisions of the new Constitution.

The Transitional Government shall handover power to the party or parties that gain a majority in the National Assembly.

The said national elections shall be held no later than two years after the establishment of the Transitional Government. Provided however, that the period can be extended by the Council of Representatives for no more than six months.

\section{Article Thirteen}

There shall be a law establishing local and regional councils for local administrative purposes defined on the basis of nationality. Elections for such local and regional councils shall be held within three months of the establishment of the Transitional Govemment, wherever local conditions allow.

\section{B. Relief and Rehabilitation}

The Transitional Govemment is unequivocally determined to ensure the delivery of relief assistance to areas ravaged by war and drought. In connection with this: 


\section{Article Fourteen}

It shall give priority to the rehabilitation of those areas that have been severly affected by the war, prisoners of war, ex-prisoners of war as well as those sections of the population that have been forceably uprooted by the previous regime's policy of villagization and resettlement.

The rehabilitation of those forceably uprooted by the previous regime's policy of villagization and resettlement shall be done in accordance with their desire.

\section{Article Fifteen}

It shall take immediate steps to reconstruct or repair the infrastructure that has been destroyed or demaged by the war.

\section{Article Sixteen}

It shall give special consideration to hitherto neglected and forgotten areas.

\section{Article Seventeen}

It shall make special efforts to dispel ethnic mistrust and eradicate the ethnic hatred that have been fostered by the previous regimes.

\section{Part Five \\ Legality of the Charter}

\section{Article Eighteen}

This Charter shall serve as the supreme law of the land for the duration of the transitional period. Any law or decision that is contrary to the Charter shall be null and void.

\section{Article Nineteen}

The Amharic and the English texts of this Charter have equal authenticity. Where disparity occurs between the two languages the Council of Representatives shall decide.

\section{Article Twenty}

This Charter shall be effective upon publication in the Negarit Gazetta.

Addis Ababa this 22nd day of July 1991

Meles Zenawi

Chairman of the Conference 
Since its coming into force, the constitution proved effective in the democratic election of February 1992 and the subsequent inauguration of the members of the main institution of the state.

\section{Societal Scripts and Constitutional Law as Competing Basis for Political Order of Ethiopia}

\section{By Heinrich Scholler}

The Transitional Constitution of Ethiopia (transitional period charter of Ethiopia of 22nd July 1991) states in Art. 2 that the different National Societies, the central and the regional powers have to decide to what extent they will adopt modem constitutional law or recur to traditional organisation of their societies.

The Societal Script is the expression of intemal not-written political order, which has to be taken into consideration. Scholars have put emphasis on the fact that the Societal Script of different groups like the Tigray-amhara and the Oromo form a thesis and anti-thesis as vertical and horizontal structure in Society, which have to be reconciled. These competing structures of the different Societal Scripts could be organised in a federal system for allowing to have diversity on the regional and cultural level together with national or central unity. Modem and traditional law (Societal Scripts) must not remain an unsolved conflict.

In the Context of the Current Developments in African Constitutional Law: The Adventure of the National Conference in Togo

\section{By EA.B. van Rouveroy van Nieuwaal}

During the last hundred years, Africa has seen profound political and constitutional changes the extent of which is closely linked to the respective colonial power. The African state is a juridical entity in international law, but was it also, at the time of independence, an empirical entity?

In almost all cases the newly independent states in Africa kept a number of the European administrative officials who formerly represented the colonial state. Independence, therefore, created a gap between the international legitimacy and the internal legitimacy of many African states. 